\title{
Expression of a recombinant protein, A2 family, from Leishmania infantum (Jaboticabal strain) and its evaluation in Canine Visceral Leishmaniasis serological test
}

Expressão de uma proteína recombinante, da família A2, de Leishmania infantum (amostra Jaboticabal) e sua avaliação no teste sorológico da Leishmaniose Visceral Canina

Márcia Mariza Gomes Jusi ${ }^{1}$; Trícia Maria Ferreira de Sousa Oliveira²; Andréa Cristina Higa Nakaghi; Marcos Rogério André'; Rosangela Zacarias Machado ${ }^{1 *}$

${ }^{1}$ Laboratório de Imunoparasitologia, Departamento de Patologia Veterinária, Faculdade de Ciências Agrárias e Veterinárias, Universidade Estadual Paulista - UNESP, Jaboticabal, SP, Brasil

${ }^{2}$ Departamento de Zootecnia, Faculdade de Zootecnia e Engenharia de Alimentos, Universidade de São Paulo - USP, Pirassununga, SP, Brasil

${ }^{3}$ Faculdade de Ciências Agrárias e Sociais, Itapeva, SP, Brasil

Received February 23, 2015

Accepted April 16, 2015

\begin{abstract}
This study aimed to: express a recombinant A2 family protein of Leishmania chagasi, Jaboticabal strain; test this protein as an antigen in serological assays; and investigate its antigenicity and immunogenicity. A protein coded by an allele of the A2 gene isolated from L. chagasi was expressed in three different strains of Escherichia coli. We used 29 sera samples from Leishmune-vaccinated dogs, 482 sera samples from dogs from endemic areas (positive controls), and 170 sera samples from dogs from non-endemic areas (negative controls) in ELISA tests using soluble Leishmania antigen (SLA) and His-A2 as antigen. Expressed proteins showed, by western blotting, the expression of an $11 \mathrm{KDa}$ protein. Sixtythree percent (303/482) of the samples from endemic areas were positive by ELISA His-A2, whereas $93.1 \%$ (27/29) of Leishmune ${ }^{\circledR}$-vaccinated animals were negative by His-A2-ELISA. Anti-A2 antibodies from mice inoculated with the A2 protein were detected in slides containing amastigote forms, but not in slides containing promastigote forms. The A2 recombinant protein from $L$. chagasi may be a useful tool in the diagnosis of CVL, and further tests regarding the infection stage and the specie of parasite at which the dogs are sampled should provide a better understanding of our results.
\end{abstract}

Keywords: Leishmania infantum, A2, Escherichia coli, diagnosis, ELISA.

\section{Resumo}

Este estudo teve como objetivos expressar uma proteína recombinante da família A2 de Leishmania chagasi, amostra de Jaboticabal-SP; testar essa proteína como antígeno em testes sorológicos; e investigar a antigenicidade e imunogenicidade dessa proteína. Uma proteína codificada por um alelo do gene A2 isolado de L. chagasi foi expressa em três diferentes amostras de Escherichia coli. Foram utilizadas 29 amostras de soro de cães vacinados com Leishmune, 482 amostras de soro de cães de áreas endêmicas (controles positivos), e 170 amostras de soro de cães de áreas não-endêmicas (controles negativos) no ELISA-teste utilizando-se antígeno solúvel total de Leishmania (AST) e His-A2 como antígenos. As proteínas expressas, detectadas pelo western blotting, mostraram a expressão de uma proteína de $11 \mathrm{KDa}$. Sessenta e três por cento (303/482) das amostras de áreas endêmicas foram positivas pelo ELISA-teste, utilizando-se antígeno His-A2; e 93,1\% (27/29) dos animais vacinados com a Leishmune foram negativos. Anticorpos anti-A2 de camundongos inoculados com a proteína A2 foram detectados em lâminas contendo formas amastigotas, enquanto em lâminas contendo formas promastigotas não houve detecção de anticorpos anti-A2. A proteína recombinante $\mathrm{A} 2$ pode ser uma ferramenta útil no diagnóstico da LVC, e maiores estudos sobre o estágio de infecção e a espécie de parasita dos cáes amostrados devem prover melhor entendimento dos resultados encontrados.

Palavras-chave: Leishmania infantum, A2, Escherichia coli, diagnóstico, ELISA.

*Corresponding author: Rosangela Zacarias Machado. Laboratório de Imunoparasitologia, Departamento de Patologia Veterinária, Faculdade de Ciências Agrárias e Veterinárias, Universidade Estadual Paulista "Júlio de Mesquita Filho" - UNESP, Campus de Jaboticabal, Via de Acesso Prof. Paulo Donato Castellane, s/n, Zona Rural, CEP 14884-900, Jaboticabal, SP, Brasil. e-mail: zacarias@fcav.unesp.br 


\section{Introduction}

Over $90 \%$ of visceral leishmaniasis cases (also called Kalazar) occur in Bangladesh, Brazil, Ethiopia, India, South Sudan and Sudan. This disease is caused by Leishmania infantum, which belongs to the Leishmania donovani complex (WHO, 2014), and, in Brazil, is mainly transmitted by the sandy fly Lutzomyia longipalpis (Diptera: Psychodidae), although Lutzomyia cruzi has also been described as a potential vector (TRAVI et al., 2002; SANTOS et al., 1998).

Although visceral leishmaniasis (VL) also occurs in humans, its prevalence is much higher in dogs than in humans (ALENCAR, 1978). Moreover, dogs have a greater number of skin parasites compared to humans, which promote infection by blood-sucking sand flies (TRAVI et al., 2001; QUEIROZ et al., 2010; JUSI et al., 2011). Therefore, dogs play an important role in contribuiting to our understanding of CVL epidemiology.

The diagnosis of CVL is difficult because dogs present variety of clinical signs and many dogs are asymptomatic; also there is currently no test for CVL with $100 \%$ specificity and sensitivity (GENARO, 1993). Serological tests such as Indirect Fluorescence Antibody Test (IFAT), Enzyme-Linked Immunosorbent Assays (ELISAs), dot-ELISA, Direct Agglutination Test, Western Blotting, and the Lateral Immunochromatographic test are commonly used for diagnosing CVL. In Brazil, one of the most employed methods for controlling CVL is based on the removal of seropositive dogs for Leishmania sp., which has been questioned by several authors (PARANHOS-SILVA et al., 1998; COURTENAY et al., 2002). Nunes et al. (2010) point out that the euthanasia of dogs has reduced human infections, but the authors also indicate the need for other preventive measures for the success of this measure such as vector control and treatment of infected humans.

Recombinant antigens such as "A2" and "K39" have been assessed in an attempt to develop simpler, faster, and more specific serological diagnosis for leishmaniasis. Charest \& Matlashewski (1994) isolated and expressed a protein from the A2 multigene family from $L$. donovani infantum, which was recognized by $60 \%$ and $82 \%$ of humans with visceral leishmaniasis (VL) in India and Sudan, respectively, using ELISA. Moreover, Carvalho et al. (2002), using a recombinant $\mathrm{A} 2$ protein from Leishmania donovani in an ELISA test, found a seroprevalence of $77 \%$ in symptomatic VL patients and $87 \%$ among positive dogs in Brazil. Genes in the A2 family are abundantly transcribed and translated during the amastigote stage of the $L$. donovani complex, but are not expressed during the promastigote stage (CHAREST \& MATLASHEWSKI, 1994; GHEDIN et al., 1997; ZHANG \& MATLASHEWSKI, 2001; FARAHMAND et al., 2008). There is evidence that the A2 protein is produced in response to stress and plays an important role in the survival of $L$. donovani in visceral organs (MCCALL \& MATLASHEWSKI, 2010). These findings suggest that the A2 protein is a potential tool for the diagnosis of VL, particularly for the diagnosis of Leishmania-infected dogs.

This study aimed to evaluate the potential use of an A2 protein expressed in L. infantum (Jaboticabal strain) for serodiagnosis of CVL. Additionally, we report preliminary results on this protein's antigenicity and immunogenicity.

\section{Materials and Methods}

\section{Strain and gene isolation}

A strain of L. infantum was isolated by Machado and Tinucci-Costa (unpublished data) from a dog showing clinical signs of CVL attended at Governador Laudo Natel Veterinary Hospital in Jaboticabal, São Paulo, Brazil (OLIVEIRA et al., 2011). The dog, originally from the city of Olímpia, in the state of São Paulo, showed positive results in serological (IFAT and ELISA) (OLIVEIRA et al., 2008) and molecular (MICHALSKY et al., 2002; CORTES et al., 2004) tests for Leishmania spp. and the L. donovani complex. Leishmania infantum was isolated in culture from bone marrow in RPMI medium (Sigma) supplemented with 20\% heat-inactivated fetal calf serum (Gibco BRL), penicillin $(100 \mathrm{U} / \mathrm{ml})$, and streptomycin $(50 \mathrm{mg} / \mathrm{ml})$ and used to isolate the A2 gene. Previously, an identical 504-nucleotide A2-gene sequence [Genbank:GQ290460] was isolated in two clones from the genomic library of L. infantum (OLIVEIRA et al., 2011).

\section{Cloning, expression, and purification of the A2 recombinant protein}

The A2 gene allele was isolated by Oliveira et al. (2011) and cloned into a pGEM-T Easy vector system (Promega, Madison, USA). This cloned gene was used as a template in PCR to amplify the $\mathrm{A} 2$ gene using $0.5 \mu \mathrm{M}$ of the specific primers designed in this study. Analyses using the SignalP 3.0 Program (BENDTSEN et al., 2004) showed a high prediction of a signal peptide in the first 26 amino acids out of a total 114 amino acids. After exclusion of the signal peptide nucleotide sequence, primers $\mathrm{A} 2 \mathrm{~b}$ reverse (5' AGAATTCTTAAGACACCGGAGAAACGTC 3') and A2c forward (5' ACATATGGCTGAGCCGCACAAGGC 3') were designed, aiming to include the $N d e \mathrm{I}$ and EcoRI enzyme restriction sites, respectively. PCR cycles consisted of an initial denaturation at $94^{\circ} \mathrm{C}$ for 2 min followed by 25 amplification cycles at $94^{\circ} \mathrm{C}$ for $1 \mathrm{~min}, 51^{\circ} \mathrm{C}$ for $1 \mathrm{~min}, 72^{\circ} \mathrm{C}$ for $1 \mathrm{~min}$, followed by a final extension cycle at $72{ }^{\circ} \mathrm{C}$ for $7 \mathrm{~min}$. The A2b/A2c-PCR product was purified using the Silica Bead DNA Gel Extraction Kit (Fermentas Cat \# K0513) and DNA concentration was measured using a Nanodrop ND1000 spectrophotometer (Thermo Scientific, USA). This purified amplified product was subcloned into a pGEM-T easy vector system (Promega, Madison, USA). The cloning vector containing the desirable DNA insert was transformed using the One Shot Match $1^{\mathrm{TM}}-\mathrm{T} 1^{\mathrm{R}}$ Chemically Competent Cells (Invitrogen, Carlsbad, USA). The transformants were analyzed by restriction analysis and DNA sequencing. Next, the target DNA was subcloned into a pET 28a expression vector (Novagen, USA) using EcoRI and NdeI sites. The pET 28a-A2 containing the target-sequence was transformed in three different E. coli strains, named BL21 (DE3), ER2566, and Rosetta competent cells. To confirm the correct direction of this construction, a PCR using the $\mathrm{A} 2 \mathrm{~b}$ reverse primer and $\mathrm{T} 7$ promoter primer from pET 28a vector (5' - TAATACGACTCACTATAGGG - 3') was 
performed. The induction of expression of the histidine-tagged recombinant protein (His6-A2) was performed in LB medium containing $0.2 \%$ glucose and $50 \mu \mathrm{g} / \mathrm{mL}$ kanamycin. The expression of His-A2 (11 kDa) was induced by $0.5 \mathrm{mM}$ IPTG (Isopropyl- $\beta$ D-thiogalactopyranoside, Thermo Scientific) at $250 \mathrm{rpm}$ and $37^{\circ} \mathrm{C}$. Samples of the bacteria extract were collected after $6 \mathrm{~h}$ for ER2266 and Rosetta and after $3 \mathrm{~h}$ for BL21. Protein expression was analyzed by $12 \%$ sodium dodecyl sulfate-polyacrilamide gel electrophoresis (SDS-PAGE) (LAEMMLI, 1970) and Westernblotting (TOWBIN et al., 1979), using the polyclonal anti-histidine mouse antibody (Sigma, St. Louis, USA.).

\section{Canine sera samples}

A total of 681 canine sera samples were used for evaluation of the His6-A2-ELISA:

(i) Negative controls: included 170 dogs sampled from Jaboticabal $\left(21^{\circ} 15^{\prime} 17^{\prime \prime} \mathrm{S} / 48^{\circ} 19^{\prime} 20^{\prime \prime} \mathrm{W}\right)$, state of São Paulo, a non-endemic area for CVL. These dog sera samples previously showed negative results for $L$. infantum using serologic methods (IFAT/ ELISA).

(ii) Positive controls: included 482 dogs sampled from endemic areas for CVL in Campo Grande (20 26' 34" S/54 38' $\left.47^{\prime \prime} \mathrm{W}\right)$, state of Mato Grosso do Sul, state of Tocantins ( $\left.10^{\circ} 12^{\prime} 46^{\prime \prime} \mathrm{S} / 48^{\circ} 21^{\prime} 37^{\prime \prime} \mathrm{W}\right)$, and Ilha Solteira, state of São Paulo (202 $\left.25^{\prime} 58^{\prime \prime} \mathrm{S} / 51^{\circ} 20^{\prime} 33^{\prime \prime} \mathrm{W}\right)$. These dog sera samples previously showed positive results for $L$. infantum in serologic methods (IFAT/ ELISA).

(iii) Vaccinated dogs (Leishmune ${ }^{\circledR}$ [Fort Dodge]): included 29 Leishmune $^{\circledR}$ vaccinated dogs, whose sera samples were kindly supplied by Fort Dodge Animal Health Company, USA.

\section{ELISA using Soluble Leishmania Antigen (SLA)}

The ELISA method used was the one described by Oliveira et al. (2008) for L. infantum with a few modifications. Microtiter immunoassay plates (Polysorp Nunclon ${ }^{\text {TM }}$ Surface. Nunc, Denmark) were coated with soluble Leishmania antigens (SLA) $(10 \mu \mathrm{g} / \mathrm{mL}$ of protein concentration) in $100 \mu \mathrm{L}$ of sodium bicarbonate-carbonated $0.05 \mathrm{M}$ buffer ( $\mathrm{pH} 9.6$ ) for $18 \mathrm{~h}$ at $4{ }^{\circ} \mathrm{C}$. The previous day, plates were washed three times with $0.05 \%$ PBS Tween-20 (PBST). Free binding sites were blocked with $5 \%$ nonfat dry milk solution for $1.5 \mathrm{~h}$ at $37^{\circ} \mathrm{C}$. After three washes with $0.05 \%$ PBST, plates were incubated $\left(1.5 \mathrm{~h}\right.$ at $\left.37^{\circ} \mathrm{C}\right)$ with $100 \mu \mathrm{L}$ of positive and negative canine sera samples (previously IFAT), diluted 1:400 in PBST with $5 \%$ nonfat dry milk. One hundred $\mu \mathrm{L}$ of alkaline phosphatase conjugated anti-dog IgG (Sigma-Aldrich, St. Louis, USA) diluted at 1: 4.000 in PBS Tween-20 with 5\% nonfat dry milk was added to each well, followed by incubation for 90 minutes at $37{ }^{\circ} \mathrm{C}$. Plates were washed and a $100 \mu \mathrm{L}$ dietanolamine solution (pH 9.8) containing a substrate for phosphatase (4-nitrophenyl phosphate disodium salt hexahydrate, Sigma) was added into each well.
Absorbance of each serum sample was measured after $30 \mathrm{~min}$ of incubation at room temperature using an ELISA reader at $405 \mathrm{~nm}$ (Dynex Technologies, USA). The discriminating absorbance value (cut-off) was determined as being equal to two and a half times the mean absorbance value of the negative group (OLIVEIRA et al., 2008), whereas values equal to or greater than the cut-off value were considered positive.

\section{ELISA using the A2 protein recombinant as antigen}

Microtiter immunoassay plates (Maxisorp Nunclon ${ }^{\text {TM }}$ Surface. Nunc, Denmark) were coated with His6-A2 recombinant protein (protein concentration was adjusted to 2.5, 5, 10, 20, and $40 \mu \mathrm{g} / \mathrm{mL}$ ) in $100 \mu \mathrm{L}$ of sodium bicarbonate-carbonated $0.05 \mathrm{M}$ buffer ( $\mathrm{pH}$ 9.6) for $18 \mathrm{~h}$ at $4{ }^{\circ} \mathrm{C}$. After this procedure the plates were washed three times with $0.05 \%$ PBS Tween 80 (PBST). Free binding sites were blocked with $2 \%$ nonfat dry milk solution for $2 \mathrm{~h}$ at $37^{\circ} \mathrm{C}$. After three washes with $0.05 \%$ PBST, plates were incubated $\left(1 \mathrm{~h}\right.$ at $37^{\circ} \mathrm{C}$ ) with $100 \mu \mathrm{L}$ positive and negative canine sera samples (previously determined with IFAT), diluted 1:50, 1:100, and 1:200 in PBST with 2, 3, and 5\% nonfat dry milk for each dilution. One hundred $\mu \mathrm{L}$ of alkaline phosphatase conjugated anti-dog IgG (Sigma-Aldrich, St. Louis, USA) diluted at 1: 4.000 in PBS Tween-20 with 5\% nonfat dry milk was added to each well, followed by incubation for 60 minutes at $37^{\circ} \mathrm{C}$. Plates were washed and a $100 \mu \mathrm{L}$ dietanolamine solution ( $\mathrm{pH}$ 9.8) containing a substrate for phosphatase (4-nitrophenyl phosphate disodium salt hexahydrate, Sigma) was added into each well. Absorbance of each serum sample was measured after $45 \mathrm{~min}$ incubation at room temperature using an ELISA reader at $405 \mathrm{~nm}$ (Dynex Technologies, USA). The discriminating absorbance value (cut-off) was determined as being equal to two and a half times the mean absorbance value of the negative group (OLIVEIRA et al., 2008), whereas values equal to or greater than the cut-off value were considered positive. ELISA results are presented as ELISA levels, to this, the optical density for the antigen-antibody reaction of each serum from each animal was ranked from 0 (lowest level) to 9 (highest level) using optical density (OD) intervals, as described by Machado et al. (1997).

\section{Western blot analysis}

Expressed unpurified protein extract and purified recombinant protein were separated by electrophoresis (Mini-Protean II, Bio-Rad, Hercules, CA, USA) in a $12 \%$ gradient polyacrylamide gel with sodium dodecyl sulfate (LAEMMLI, 1970). The transfer to nitrocellulose membranes was performed as previously described (TOWBIN et al., 1979). Membranes were blocked with 5\% nonfat dry milk and $0.05 \%$ Tween-20 in Tris buffered saline (TBS: $20 \mathrm{mM}$ Tris, $500 \mathrm{mM} \mathrm{NaCl}, \mathrm{pH} \mathrm{7.5)}$ for $12 \mathrm{~h}$ at $4{ }^{\circ} \mathrm{C}$. For immunodetection, nitrocellulose membranes were assayed with monoclonal anti-polyhistidine (Sigma, St. Louis, USA) diluted 1:3000 in PBS-Tween with 5\% nonfat dry milk for $1 \mathrm{~h}$ at room temperature. Next, membranes were washed three times (10 min each) with TBS-Tween and incubated with IgG anti-mouse alkaline phosphatase conjugate (Sigma, St. Louis, 
USA, cat. A-3562) for $90 \mathrm{~min}$. Conjugate was removed and three washes (10 min each) were performed using TBS-Tween. The polypeptide bands were visualized by the addition of the enzyme substrate 5-bromo-4-chloro-3-indoyl phosphate/nitroblue tetrazolium chloride (NBT-BCIP, Bio-Rad, Hercules, CA, USA). Colorimetric reactions were stopped by washing the membranes in distilled water.

\section{Mice}

His6_A2 (10 mg) immunogenicity was verified by immunization of six- to eight-week old SPF BALB / c mice (MACHADO et al., 1994). Blood samples were collected by intracardiac puncture on the $10^{\text {th }}$ day after the last immunization, and sera were stored at $-20{ }^{\circ} \mathrm{C}$ until analyzed. Animals from groups A, B, and C were euthanized according to ethical principles in animal experimentation adopted by the Brazilian College of Animal Experimentation (COBEA) and approved by the Ethics Committee on Animal Use (CEUA), protocol number 005965/11.

\section{Indirect Fluorescence Antibody Test (IFAT)}

The presence of anti-A2 antibodies in immunized mice sera was assessed using amastigote and promastigote forms of $L$. infantum as antigens in an Immunofluorescence Indirect Assay (IFA). To obtain amastigote forms, axenic promastigotes were maintained in culture according to the methodology of Bahrami et al. (2011), whereas promastigotes were obtained according to the methodology described by Oliveira et al. (2008). Leishmania sp. promastigotes or amastigotes were washed three times in PBS and resuspended in PBS-buffered formalin (4\%) for $30 \mathrm{~min}$. Three additional washes in PBS were performed and the pellet was resuspended in PBS (up to $3-4 \times 10^{6}$ parasites per $\mathrm{mL}$ ). Slides with 12 previously marked circles (Perfecta LTDA, São Paulo, Brazil) were covered with $10 \mu \mathrm{L}$ of the solution onto each circle, air-dried, wrapped in a soft paper, and then frozen at $-20{ }^{\circ} \mathrm{C}$ until use. Slides containing promastigotes or amastigotes were stabilized at room temperature for the IFAT procedure. Sera samples were diluted 1:32, placed on slides covered with $L$. infantum -antigen, and incubated in a moist chamber at $37^{\circ} \mathrm{C}$ for $30 \mathrm{~min}$. Slides were washed three times in PBS and incubated with anti-mouse IgG serum conjugated with fluorescein isothiocyanate (Sigma, St. Louis, USA, cat. F0257) diluted 1:64 in PBS containing $1 \mathrm{mg}$ of Evan's Blue. Slides were washed three times in PBS, once in distillated water, and covered with buffered glycerin using a cover slip, followed by examination in a fluorescent microscope (Olympus, BX-FLA).

\section{Statistical analysis}

The diagnostic sensitivity, specificity, and accuracy of the single dilution ELISA for the detection of anti-A2 antibodies were determined in comparison to the SLA. Test results were analyzed for inter-assay agreement with SLA using kappa statistics (described in MOHAN et al., 2006).

\section{Results}

\section{Expression of $A 2$ recombinant protein}

A2b/A2c-PCR products resulted in a $280 \mathrm{bp}$ fragment. Multiple sequence alignment was performed to compare the identity of the Jaboticabal strain-L. infantum A2 amino acid sequence with the amino acid sequence of the same protein from different Leishmania sp.-isolates. The A2 recombinant protein was expressed in a soluble form by three different strains of E. coli (BL21, ER 2566, and Rosetta). Sufficient amounts of pure protein $(334.0 \mu \mathrm{g} / \mathrm{mL}$ for BL21; 328.25 $\mu \mathrm{g} / \mathrm{mL}$ for ER 2566; and $411.5 \mu \mathrm{g} / \mathrm{mL}$ for Rosetta) were obtained in the single-step purification by immobilized metal-affinity chromatography. SDS-PAGE and Western blotting analysis using the polyclonal anti-histidine mouse antibodies revealed an $11 \mathrm{KDa}$ molecular weight protein of the recombinant His6-A2 (Figure 1).

\section{ELISA}

To evaluate the potential of the expressed His6-A2 as a suitable antigen for the serodiagnosis of $L$. infantum infection, the purified His6-A2 was tested in an ELISA using sera samples

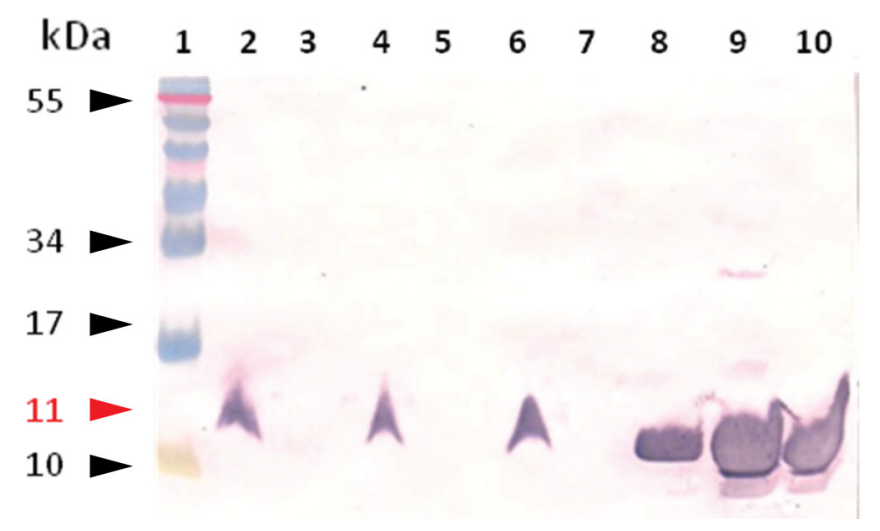

Figure 1. Western blot analysis of A2 protein. The samples are, respectively: lane 1, Prestained Protein Ladder (Fermentas); lane 2, BL21 (DE3) extract, induced by IPTG, transformed with the construction pET28a_A2; lane 3, BL21 (DE3) extract, not induced by IPTG, transformed with the construction pET28a_A2; lane 4, ER2566 extract, induced by IPTG, transformed with the construction pET28a_A2; lane 5, ER 2566 extract, not induced by IPTG, transformed with the construction pET28a_A2; lane $\mathbf{6}$, Rosetta extract, induced by IPTG, transformed with the construction pET28a_A2; lane 7, Rosetta extract, not induced by IPTG, transformed with the construction pET28a_A2; lane 8, purified A2protein, originated from BL21 (DE3), induced by IPTG, transformed with the construction pET28a (3 $\mu \mathrm{g} /$ well); lane 9, purified A2 protein originated from Rosetta, induced by IPTG, transformed with the construction pET28a_A2 (7 $\mu \mathrm{g} /$ well); lane 10, purified A2 protein originated from ER2566, induced by IPTG, transformed with the

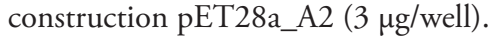


from L. infantum -naturally infected dogs, sera samples from dogs from a non-endemic area for leishmaniasis, and sera samples from Leishmune ${ }^{\circledR}$-vaccinated dogs. The conditions showing an ideal discrimination between negative and positive reference dog sera samples were: an antigen concentration (from BL21 strain) of $2.5 \mu \mathrm{g} / \mathrm{mL}$ in carbonate buffer, $\mathrm{pH} 9.6$, blocked with nonfat dry milk (3\%), using PBS Tween 80, sera samples diluted 1:50, and anti-dog IgG alkaline phosphatase antibody diluted 1:4000 (Sigma, St. Louis, USA, cat. A6042). The cut-off value was 0.282 (level 3). From positive controls, positive samples by SLA ELISA, $63 \%$ (from a total of 482 samples) were positive by ELISA His-A2 and $93.1 \%$ (from a total of 29 samples) of Leishmune ${ }^{\circledR}$-vaccinated animals were negative by ELISA His-A2 (Figures 2, 3, and 4). Table 1 shows the sensitivity, specificity, and the accuracy of the assay relative to the reference ELISA method using SLA as antigen. The kappa value was 0.47 , which represents an agreement of $47 \%$

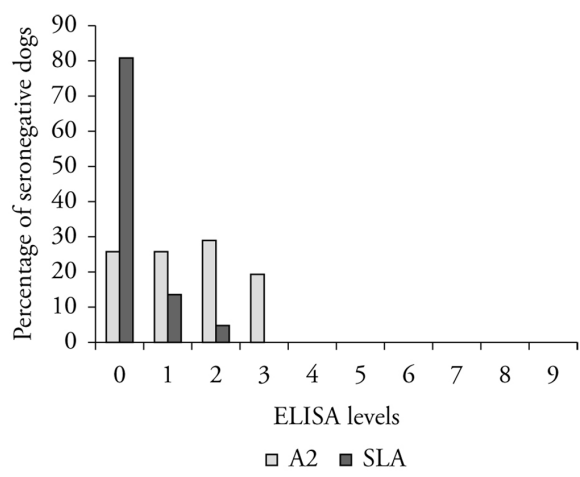

Figure 2. Percentage of seronegative $\operatorname{dogs}(\mathrm{n}=170)$ according to ELISA levels using L. infantum chagasi soluble and His-A2 as ELISA antigens.

Table 1. Relative sensitivity, specificity, and accuracy values of developed ELISA to detect anti-A2 antibodies using SLA as a reference standard.

\begin{tabular}{llll}
\hline & SLA & & \\
\cline { 2 - 4 } A2 & + & - & Total \\
\hline+ & $304^{\mathrm{a}}$ & $0^{\mathrm{b}}$ & 304 \\
- & $178^{\mathrm{c}}$ & $170^{\mathrm{d}}$ & 348 \\
Total & 482 & 170 & 652 \\
\hline
\end{tabular}

${ }^{2}$ Sensitivity $=304 / 482 \times 100=63 \%$. ${ }^{b}$ Specificity $=170 / 170 \times 100=100 \%$. ${ }^{\mathrm{c}}$ Accuracy $=474 / 652 \times 100=72.7 \%$. ${ }^{\mathrm{d}}$ Kappa value $=0.47$. SLA - Soluble Leishmania antigen (single dilution 1:400).

Table 2. Density Opticals values for ELISA levels 0-9.

\begin{tabular}{cc}
\hline ELISA levels & DO intervals \\
\hline 0 & $0-0.115$ \\
1 & $0.116-0.155$ \\
2 & $0.156-0.209$ \\
3 & $0.210-0.282$ \\
4 & $0.283-0.381$ \\
5 & $0.382-0.515$ \\
6 & $0.516-0.696$ \\
7 & $0.697-0.939$ \\
8 & $0.940-1.268$ \\
9 & $>1.269$ \\
\hline
\end{tabular}

between A2-ELISA and SLA-ELISA from a total of 652 sera samples (vaccinated animals were not included in this analysis). The ELISA levels were determined as shown in Table 2.

\section{Indirect Fluorescence Antibody Test (IFAT)}

Anti-A2 protein antibodies were detected in slides containing amastigote forms, but not in slides containing promastigote forms, showing that A2 family proteins were found only in this phase (Figure 5). These results confirm the antigenic and immunogenic properties of the expressed protein.

\section{Discussion}

Many studies have been demonstrated the limitations to identify asymptomatic dogs using the available tests (DYE et al., 1992; REITHINGER et al., 2002; RHALEM et al., 1999). Porrozzi et al. (2007) showed that ELISA based on crude antigens shown minor percentage (30\%) for asymptomatic dogs than that ELISA based on recombinant leishmanial antigens rA2 (88\%); rK39 and rK26 (66\%). Thus, many efforts have been done to development more sensitive, specific and rapid tests to detection of CVL helping in epidemiology and to control the disease (ZIJLSTRA et al., 2001; ATTAR et al., 2001; MOHEBALI et al., 2004; AKHOUNDI et al., 2013).

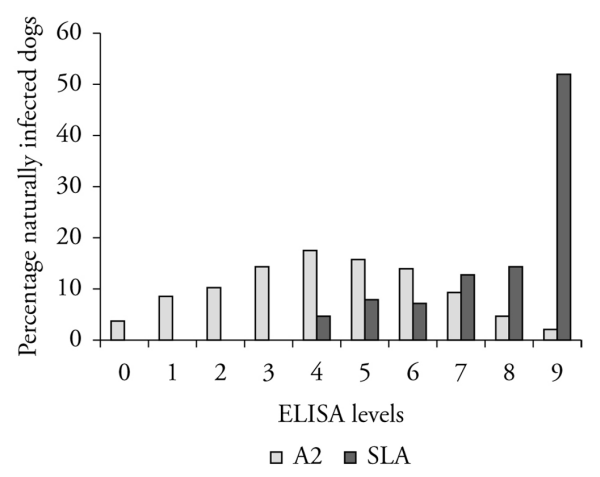

Figure 3. Percentage of seropositive naturally infected dogs $(n=482)$ according to ELISA levels using L. infantum chagasi soluble and His-A2 as ELISA antigens.

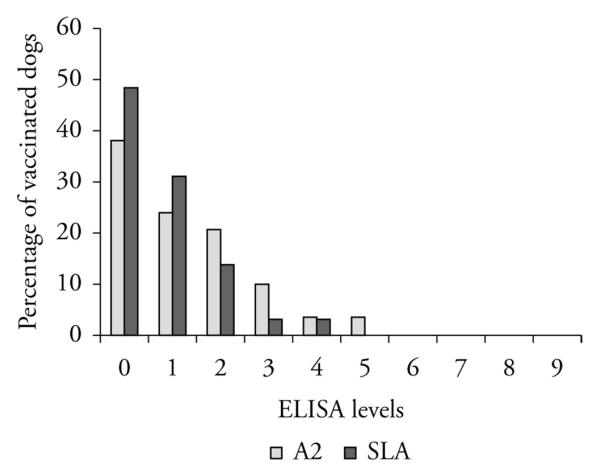

Figure 4. Percentage of sera from Leishmune ${ }^{\circledR}$-vaccinated dogs ( $\mathrm{n}=29)$ according to ELISA levels using L. infantum chagasi soluble and His-A2 as ELISA antigens. 

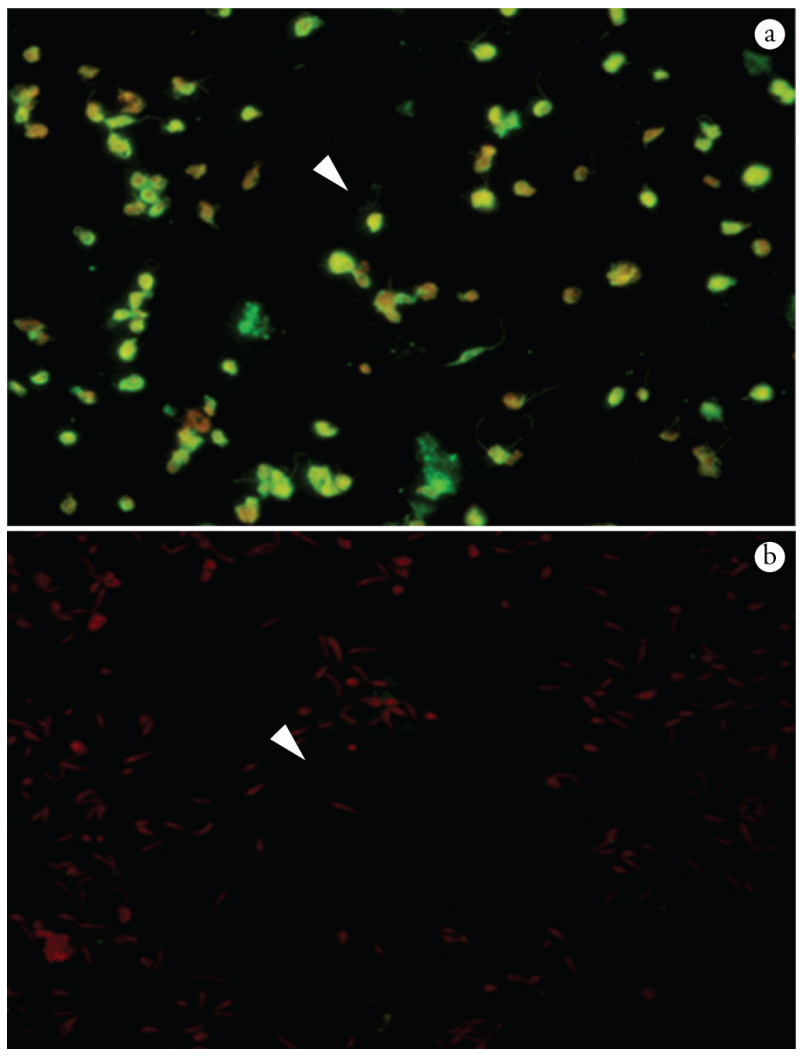

Figure 5. Fluorescence patterns of IFAT using L. infantum chagasi amastigote and promastigote forms as antigen. (a) IFAT using amastigote forms as antigen, showing a positive fluorescent reaction due to the presence of anti-A2 antibodies in mice sera samples immunized with His-A2 protein in Freund's adjuvant. (b) IFAT using promastigote forms as antigen, showing a negative fluorescent reaction due to the lack of the A2 protein in this stage of parasite in mice sera samples immunized with His-A2 protein in Freund's adjuvant.

The production of recombinant antigens from the cloning and expression of heterologous proteins in prokaryotic or eukaryotic systems represents a relevant and effective alternative for preparing large amounts of highly purified antigens to be used in serological tests. Thus, the production of recombinant antigens may also be an alternative for the serodiagnosis of CVL. A2 family proteins of $L$. donovani have been shown to be immunogenic and specific to the amastigote stage of this parasite (CHAREST \& MATLASHEWSKI, 1994). Antibodies against the $A 2$ protein have also been detected in dogs and humans infected with $L$. donovani or L. mexicana. However, antibodies to A2 have not been detected in humans with the cutaneous form of the disease (GHEDIN et al., 1997; CARVALHO et al., 2002).

This study, in which an A2 protein was isolated from L. infantum, also supports the study of Ghedin et al. (1997), in which karyotypic analysis performed in several species of Leishmania showed that A2 genes are conserved in L. infantum. The A2 locus is comprised of at least seven genes, which differ in the length of the sequences encoding the repeat peptide unit (CHAREST et al., 1996). Although A2 protein length ranges from 45 to $100 \mathrm{kDa}$ (ZHANG et al., 1996), the A2 gene isolated by
Oliveira et al. (2011) has a length of 495 base pairs. However, after clone sequence analysis, we observed that the amino acid sequence had a predicted signal peptide in the first 26 amino acids. Thus, we excluded this sequence from our construct to avoid solubility problems in the expression, rendering an expressed protein with a final size of $11 \mathrm{KDa}$.

All three different strains of E. coli competent cells used in this study satisfactorily expressed the recombinant A2 protein. The expression of proteins in E. coli has many advantages over other systems for cloning and gene expression such as ease of handling, use of relatively simple media, and rapid protein expression. Moreover, the processes of extraction and purification of recombinant proteins is straightforward, which is advantageous for large-scale protein production. Lastly, despite not allowing post-translational modifications, proteins expressed in E. coli have been used successfully in diagnostic tests for different diseases in veterinary medicine (MCBRIDE et al., 1999; HUANG et al., 2006).

Although most of the sera samples obtained from L. infantum -naturally infected dogs showed high ELISA levels (63\% of 482 seropositive dogs), 37\% did not show antibodies to the A2 recombinant protein. This lack of A2 antibodies may be related to the phase of the disease at which dogs were sampled and to the fact that all positive samples were tested by serology tests only. Then, we must consider cross-reaction with other species of the parasite. For example, animals infected with L. braziliensis, which does not produce the A2 protein and it will be negative in ELISA_A2, but positive in ELISA_SLA. The investigation of A2 expression may indicate the leishmaniasis stage in infected dogs. Additional investigation with symptomatic and asymptomatic dogs, done by parasitological tests, may provide further information for a better understanding of these results.

Porrozzi et al. (2007) showed that serologic tests using the recombinant protein $\mathrm{rK} 39$ and $\mathrm{rK} 26$ (both from L. infantum) were more efficient to identify symptomatic dogs while rA2 (from Leishmania donovani) seem to be effective for the serodiagnosis of asymptomatic dogs with the disease. Interestingly, only two of the 29 Leishmune ${ }^{\circledR}$-vaccinated animals were seropositive by A2_ELISA, and showed ELISA levels near the cut-off point. Dogs from non-endemic areas with previously negative results with L. infantum-IFAT and SLA-ELISA studies were also negative by A2_ELISA. Further studies are needed to improve the specificity of the developed assay and more satisfactory results using the A2 protein for serodiagnosis of VL could probably be achieved by using a broader spectrum of proteins instead of a single protein (GHEDIN et al., 1997; PORROZZI et al., 2007; COSTA et al., 2012). Moreover, the high specificity and sensibility of crude antigen compared to the soluble recombinant protein is due to the broad spectrum of protein available for antibody binding.

As already mentioned, A2 family proteins are expressed in the amastigote stage of the parasite, while Leishmania is located in the fagolisossomal compartment of the vertebrate host macrophage. In this study, we associated this finding with results obtained in IFAT, in which His-A2 immunized mice sera samples only showed positive results in slides containing amastigotes as antigen.

Moreover, the immunogenicity and antigenicity of the recombinant A2 protein were confirmed by the production of specific antibodies by mice experimentally inoculated with His-A2. 
The A2 recombinant protein from $L$. donovani has been tested also in vaccine development including a disponible commercial vaccine, Leish-Tec ${ }^{\circledR}$ (CARVALHO et al., 2002; FERNANDES et al., 2008; TESTASICCA et al., 2014). Further research and novel protocols are being developed to obtain a better characterization of this newly expressed recombinant protein.

\section{Acknowledgements}

The authors thank FAPESP (Fundação de Amparo à Pesquisa do Estado de São Paulo), Process \# 2011/17594-5 and 2011/01961-9 and CAPES (Coordenação de Aperfeiçoamento de Pessoal de Nível Superior) for fellowship and financial support.

\section{References}

Akhoundi B, Mohebali M, Shojaee S, Jalali M, Kazemi B, Bandehpour $\mathrm{M}$, et al. Rapid detection of human and canine visceral leishmaniasis: assessment of a latex agglutination test based on the A2 antigen from amastigote forms of Leishmania infantum. Exp Parasitol 2013; 133(3): 307313. http://dx.doi.org/10.1016/j.exppara.2012.12.002. PMid:23276878.

Alencar JE. Leishmaniose Visceral no Brasil. Rev Med UFC 1978; 17/18: 129-148.

Attar ZJ, Chance ML, el-Safi S, Carney J, Azazy A, El-Hadi M, et al. Latex agglutination test for the detection of urinary antigens in visceral leishmaniasis. Acta Trop 2001; 78(1): 11-16. http://dx.doi.org/10.1016/ S0001-706X(00)00155-8. PMid:11164745.

Bahrami S, Hatam GR, Razavi M, Nazifi S. In vitro cultivation of axenic amastigotes and the comparison of antioxidant enzymes at different stages of Leishmania tropica. Trop Biomed 2011; 28(2): 411-417. PMid:22041763.

Bendtsen JD, Nielsen H, von Heijne G, Brunak S. Improved prediction of signal peptides: signalP 3.0. J Mol Biol 2004; 340(4): 783-795. http:// dx.doi.org/10.1016/j.jmb.2004.05.028. PMid:15223320.

Carvalho FA, Charest H, Tavares CA, Matlashewski G, Valente EP, Rabello A, et al. Diagnosis of American visceral leishmaniasis in humans and dogs using the recombinant Leishmania donovani A2 antigen. Diagn Microbiol Infect Dis 2002; 43(4): 289-295. http://dx.doi.org/10.1016/ S0732-8893(02)00410-8. PMid:12151189.

Charest H, Matlashewski G. Developmental gene expression in Leishmania donovani: differential cloning and analysis of an amastigote-stage-specific gene. Mol Cell Biol 1994; 14(5): 2975-2984. PMid:7545921.

Charest H, Zhang WW, Matlashewski G. The developmental expression of Leishmania donovani $\mathrm{A} 2$ amastigote-specific genes is post-transcriptionally mediated and involves elements located in the 3 '-untranslated region. J Biol Chem 1996; 271(29): 17081-17090. http://dx.doi.org/10.1074/ jbc.271.29.17081. PMid:8663340.

Cortes S, Rolão N, Ramada J, Campino L. PCR as a rapid and sensitive tool in the diagnosis of human and canine leishmaniasis using Leishmania donovani s.l.-specific kinetoplastid primers. Trans $R$ Soc Trop Med Hyg 2004; 98(1): 12-17. http://dx.doi.org/10.1016/S0035-9203(03)000026. PMid:14702834.

Costa MM, Penido M, Santos MS, Doro D, Freitas E, Michalick MSM, et al. Improved canine and human visceral leishmaniasis immunodiagnosis using combinations of synthetic peptides in enzyme-linked immunosorbent assay. PLos Negl Trop Dis 2012; 6(5): 1-9.
Courtenay O, Quinnell RJ, Garcez LM, Shaw JJ, Dye C. Infectiousness in a cohort of brazilian dogs: why culling fails to control visceral leishmaniasis in areas of high transmission. J Infect Dis 2002; 186(9): 1314-1320. http://dx.doi.org/10.1086/344312. PMid:12402201.

Dye C, Killick-Kendrick R, Vitutia MM, Walton R, Killick-Kendrick M, Harith AE, et al. Epidemiology of canine leishmaniasis: prevalence, incidence and basic reproduction number calculated from a cross-sectional serological survey on the island of Gozo, Malta. Parasitology 1992; 105(1): 35-41. http://dx.doi.org/10.1017/S0031182000073662. PMid:1437274.

Farahmand M, Nahrevanian H, Assmar M, Mohebali M, Zarei Z. Expression of A2 proteins in amastigotes of Leishmania infantum produced from canine isolates collected in the district of Meshkinshahr, in northwestern Iran. Ann Trop Med Parasitol 2008; 102(1): 81-84. http://dx.doi. org/10.1179/136485908X252160. PMid:18186982.

Fernandes AP, Costa MMS, Coelho EAF, Michalick MSM, Freitas E, Melo MN, et al. Protective immunity against challenge with Leishmania (Leishmania) chagasi in beagle dogs vaccinated with recombinant A2 protein. Vaccine 2008; 26(46): 5888-5895. http://dx.doi.org/10.1016/j. vaccine.2008.05.095. PMid:18786587.

Genaro O. Leishmaniose visceral canina experimental [Thesis]. Belo Horizonte: Universidade Federal de Minas Gerais; 1993.

Ghedin E, Zhang WW, Charest H, Sundar S, Kenney RT, Matlashewski G. Antibody response against a Leishmania donovani amastigote-stagespecific protein in patients with visceral leishmaniasis. Clin Diagn Lab Immunol 1997; 4(5): 530-535. PMid:9302200.

Huang X, Xuan X, Yokoyama N, Katayama Y, Anzai T, Igarashi I. Evaluation of enzyme-linked immunosorbent assays with recombinant antigens for the serodiagnosis of equine Babesia infections. Vet Parasitol 2006; 140(1-2): 158-161. http://dx.doi.org/10.1016/j.vetpar.2006.03.013. PMid:16621293.

Jusi MMG, Starke-Buzetti WA, Oliveira TMFS, Tenório MS, Sousa LO, Machado RZ. Molecular and serological detection of Leishmania spp. in captive wild animals from Ilha Solteira, SP, Brazil. Rev Bras Parasitol Vet 2011; 20(3): 219-222. http://dx.doi.org/10.1590/S198429612011000300008 . PMid:21961752.

Laemmli UK. Cleavage of structural proteins during the assembly of the head of bacteriophage T4. Nature 1970; 227(5259): 680-685. http:// dx.doi.org/10.1038/227680a0. PMid:5432063.

Machado RZ, Montassier HJ, Pinto AA, Lemos EG, Machado MR, Valadão IF, et al. An enzyme-linked immunosorbent assay (ELISA) for the detection of antibodies against Babesia bovis in cattle. Vet Parasitol 1997; 71(1): 17-26. http://dx.doi.org/10.1016/S0304-4017(97)000034. PMid:9231985.

Machado RZ, Valadão CA, Melo WR, Alessi AC. Isolation of Babesia bigemina and Babesia bovis merozoites by ammonium chloride lysis of infected erythrocytes. Braz J Med Biol Res 1994; 27(11): 2591-2598. PMid:7549981.

McBride JW, Yu X, Walker DH. Molecular cloning of the gene for a conserved major immunoreactive 28-kilodalton protein of Ehrlichia canis: a potential serodiagnostic antigen. Clin Diagn Lab Immunol 1999; 6(3): 392-399. PMid:10225842.

McCall LI, Matlashewski G. Localization and induction of the A2 virulence factor in Leishmania: evidence that A2 is a stress response protein. Mol Microbiol 2010; 77(2): 518-530. http://dx.doi.org/10.1111/j.13652958.2010.07229.x. PMid:20497497. 
Michalsky EM, Fortes-Dias CL, Pimenta PF, Secundino NF, Dias ES. Assessment of PCR in the detection of Leishmania spp. in experimentally infected individual phlebotomine sandflies (Diptera: Psychodidae: Phlebotominae). Rev Inst Med Trop Sao Paulo 2002; 44(5): 255-259. http://dx.doi.org/10.1590/S0036-46652002000500004. PMid:12436164.

Mohan CM, Dey S, Rai A, Kataria JM. Recombinant haemagglutinin neuraminidase antigen-based single serum dilution ELISA for rapid serological profiling of Newcastle disease virus. J Virol Methods 2006; 138(1-2): 117-122. http://dx.doi.org/10.1016/j.jviromet.2006.08.002. PMid:16978713.

Mohebali M, Taran M, Zarei Z. Rapid detection of Leishmania infantum infection in dogs: comparative study using an immunochromatographic dipstick rk39 test and direct agglutination. Vet Parasitol 2004; 121(3-4): 239-245. http://dx.doi.org/10.1016/j.vetpar.2004.02.014. PMid:15135863.

Nunes CM, Pires MM, Silva KM, Assis FD, Gonçalves J Fo, Perri SHV. Relationship between dog culling and incidence of human visceral leishmaniasis in an endemic area. Vet Parasitol 2010; 170(1-2): 131133. http://dx.doi.org/10.1016/j.vetpar.2010.01.044. PMid:20181428.

Oliveira TMFS, Furuta PI, Carvalho D, Machado RZ. A study of crossreactivity in serum samples from dogs positive for Leishmania sp., Babesia canis and Ehrlichia canis in enzyme-linked immunosorbent assay and indirect fluorescent antibody test. Rev Bras Parasitol Vet 2008; 17(1): 7-11. PMid:18554433.

Oliveira TMFS, Vasconcelos EJ, Nakaghi ACH, Defina TPA, Jusi MMG, Baldani CD, et al. A novel A2 allele found in Leishmania (Leishmania) infantum chagasi. Rev Bras Parasitol Vet 2011; 20(1): 42-48. http://dx.doi. org/10.1590/S1984-29612011000100009. PMid:21439231.

Paranhos-Silva M, Nascimento EG, Melro MCBF, Oliveira GGS, dos Santos WL, Pontes-de-Carvalho LC, et al. Cohort study on canine emigration and Leishmania infection in an endemic area for American visceral leishmaniasis. Implications for the disease control. Acta Trop 1998; 69(1): 75-83. http://dx.doi.org/10.1016/S0001-706X(97)00116-2. PMid:9588243.

Porrozzi R, Santos da Costa MV, Teva A, Falqueto A, Ferreira AL, dos Santos $\mathrm{CD}$, et al. Comparative evaluation of enzyme-linked immunosorbent assays based on crude and recombinant leishmanial antigens for serodiagnosis of symptomatic and asymptomatic Leishmania infantum visceral infections in dogs. Clin Vaccine Immunol 2007; 14(5): 544-548. http://dx.doi. org/10.1128/CVI.00420-06. PMid:17314229.

Queiroz NM, Assis J, Oliveira TMFS, Machado RZ, Nunes CM, StarkeBuzetti WA. Canine visceral leishmaniasis diagnosis by immunohistochemistry and PCR in skin tissues in association with IFAT and ELISA-test. Rev Bras Parasitol Vet 2010; 19(1): 32-38. PMid:20385057.

Reithinger R, Quinnell RJ, Alexander B, Davies CR. Rapid detection of Leishmania infantum infection in dogs: comparative study using an immunochromatographic dipstick test, enzyme-linked immunosorbent assay, and PCR. J Clin Microbiol 2002; 40(7): 2352-2356. http://dx.doi. org/10.1128/JCM.40.7.2352-2356.2002. PMid:12089247.

Rhalem A, Sahibi H, Guessous-Idrissi N, Lasri S, Natami A, Riyad $\mathrm{M}$, et al. Immune response against Leishmania antigens in dogs naturally and experimentally infected with Leishmania infantum. Vet Parasitol 1999; 81(3): 173-184. http://dx.doi.org/10.1016/S0304-4017(98)00240-4. PMid:10190861.

Santos SO, Arias J, Ribeiro AA, Hoffmann MP, Freitas RA, Malacco MA. Incrimination of Lutzomyia cruzi as a vector of American visceral leishmaniasis. Med Vet Entomol 1998; 12(3): 315-317. http://dx.doi. org/10.1046/j.1365-2915.1998.00104.x. PMid:9737605.

Testasicca MC, Santos MS, Machado LM, Serufo AV, Doro D, Avelar $\mathrm{D}$, et al. Antibody responses induced by Leish-Tec ${ }^{\circledR}$, an A2-based vaccine for visceral leishmaniasis, in a heterogeneous canine population. Vet Parasitol 2014; 204(3-4): 169-176. http://dx.doi.org/10.1016/j. vetpar.2014.04.025. PMid:24863572.

Towbin H, Staehelin T, Gordon J. Electrophoretic transfer of proteins from polyacrylamide gels to nitrocellulose sheets: procedure and some applications. Proc Natl Acad Sci USA 1979; 76(9): 4350-4354. http:// dx.doi.org/10.1073/pnas.76.9.4350. PMid:388439.

Travi BL, Ferro C, Cadena H, Montoya-Lerma J, Adler GH. Canine visceral leishmaniasis: dog infectivity to sand flies from non-endemic areas. Res Vet Sci 2002; 72(1): 83-86. http://dx.doi.org/10.1053/rvsc.2001.0527. PMid:12002643.

Travi BL, Tabares CJ, Cadena H, Ferro C, Osorio Y. Canine viscera leishmaniasis in Colombia: relationship between clinical and parasitologic status and infectivity for sand flies. Am J Trop Med Hyg 2001; 64(3-4): 119-124. PMid:11442205.

World Health Organization - WHO. Leishmaniasis: burden and distribution [online]. 2014 [cited 2014 Nov 26]. Available from: http://www.who. int/leishmaniasis/burden/en.

Zhang WW, Charest H, Ghedin E, Matlashewski G. Identification and overexpression of the A2 amastigote-specific protein in Leishmania donovani. Mol Biochem Parasitol 1996; 78(1-2): 79-90. http://dx.doi. org/10.1016/S0166-6851(96)02612-6. PMid:8813679.

Zhang WW, Matlashewski G. Characterization of the A2-A2rel gene cluster in Leishmania donovani: involvement of A2 in visceralization during infection. Mol Microbiol 2001; 39(4): 935-948. http://dx.doi. org/10.1046/j.1365-2958.2001.02286.x. PMid:11251814.

Zijlstra EE, Nur Y, Desjeux P, Khalil EAG, El-Hassan AM, Groen J. Diagnosing visceral leishmaniasis with the recombinant K39 strip test: experience from the Sudan. Trop Med Int Health 2001; 6(2): 108-113. http://dx.doi.org/10.1046/j.1365-3156.2001.00680.x. PMid:11251906. 